\title{
Fetal viability and fetal growth after prolonged uterine contractions induced by progesterone withdrawal in late pregnancy in rats
}

\author{
W. Arkaravichien and K. E. Kendle* \\ School of Pharmacy, Robert Gordon Institute of Technology, Aberdeen AB9 1FR, UK
}

\begin{abstract}
Summary. The hypothesis that sustained uterine contractile activity is the direct cause of fetal death after progesterone withdrawal in late pregnancy in rats was investigated. Pregnant rats were subjected to progesterone withdrawal on day 15 of pregnancy by injecting $2 \mathrm{mg}$ mifepristone (RU 486) $\mathrm{kg}^{-1}$ or by ovariectomy with oestradiol replacement $\left(200 \mathrm{ng} \mathrm{day}^{-1}\right)$. Uterine contractile activity (force and frequency) at $4 \mathrm{~h}$, but not at $2 \mathrm{~h}$, in rats injected with mifepristone was significantly higher than in rats injected with vehicle. The contractile activity in mifepristone-treated rats remained higher than in control rats, at 12, 24 and $48 \mathrm{~h}$. Fetal viability $36 \mathrm{~h}$ after mifepristone injection, when uterine contractions had lasted for $32 \mathrm{~h}$, was not significantly different from fetal viability in rats injected with vehicle, but at $42 \mathrm{~h}$ after mifepristone injection, fetal viability was significantly reduced.
\end{abstract}

In ovariectomized rats, uterine contractile activity at $12,24,36$ and $48 \mathrm{~h}$, but not at $8 \mathrm{~h}$, was significantly greater than in ovariectomized rats with progesterone replacement $\left(4 \mathrm{mg} \mathrm{day}^{-1}\right)$. Fetal viability at $42 \mathrm{~h}$ after the operation, when uterine contractions had lasted for $30 \mathrm{~h}$, was not significantly reduced, but it was significantly reduced at $48 \mathrm{~h}$. When ovariectomized rats had been left to develop uterine contractions for a period before progesterone was injected, deprivation of progesterone and prolonged uterine contractions for about $30 \mathrm{~h}$ did not reduce fetal viability or fetal growth determined on day 18 , but it did so 3 days later, on day 21 . Administration of $5 \mathrm{mg}$ isoxuprine $\mathrm{kg}^{-1}$ twice a day, which suppressed uterine contractions, improved fetal viability in ovariectomized rats at the earlier stage, but not at the later stage. Nevertheless, isoxuprine did improve fetal growth at the later stage in these ovariectomized rats.

It is concluded that increased uterine contractile activity sustained for $32 \mathrm{~h}$ or less does not reduce fetal viability, but longer periods of contraction may be the cause of fetal death.

Keywords: fetal viability; fetal growth; uterine contractions; progesterone withdrawal; rat

\section{Introduction}

In normal parturition in rats, a decrease in plasma progesterone and a rise in plasma oestradiol increase uterine contractility required for labour, which precedes the expulsive stage of fetuses by $2-3 \mathrm{~h}$; the expulsion of the whole litter lasts for about $2 \mathrm{~h}$, on average. Uterine contractile activity remains high throughout the delivery of the litter, but disappears soon after the last fetus and placenta have been expelled (Fuchs, 1973). The whole period of active uterine contractions during parturition, therefore, lasts for about 4-5 h. Prolonged labour induced by altering the hormone dynamics during the periparturient period results in a high incidence of stillbirth and dead fetuses in utero (Inoue, 1981).

\footnotetext{
${ }^{*}$ Corresponding author.
} 
In late pregnancy in rats, progesterone withdrawal, by ovariectomy or by administration of antiprogestational steroid, also causes an increase in uterine contractility (Clabault et al., 1988; Arkaravichien \& Kendle, 1992). In our previous study (Arkaravichien \& Kendle, 1990), it was shown that progesterone replacement in rats ovariectomized on day 15 of pregnancy could be delayed up to $36 \mathrm{~h}$ after ovariectomy, when uteri might have been contracting for quite a long period, without significant reduction in fetal viability. The present study investigated further the onset of active uterine contractions after progesterone withdrawal by injecting the antiprogestational steroid mifepristone and by ovariectomy in late pregnancy in rats and investigated the effects of prolonged uterine contractions after progesterone withdrawal on fetal viability and growth.

\section{Materials and Methods}

\section{Animals and treatment}

Female Sprague-Dawley rats aged 9-13 weeks were housed in $12 \mathrm{~h}$ light and $12 \mathrm{~h}$ dark. Vaginal smears were taken every morning after pairing with male rats overnight. The day of a positive sperm smear was defined as day 1 of pregnancy. Day-15 pregnant rats were subjected to progesterone withdrawal by injecting $2 \mathrm{mg}$ mifepristone $\mathrm{kg}^{-1}$ subcutaneously or by ovariectomy followed by oestradiol benzoate replacement at $200 \mathrm{ng} \mathrm{day}^{-1}$. They were randomly allocated to different groups for determination of uterine contraction or fetal viability and fetal growth at different times after treatment.

Steroids were dissolved in sesame oil and administered subcutaneously at $0.1 \mathrm{ml}$ per rat (oestradiol and progesterone) or $1 \mathrm{~m} / \mathrm{kg}^{-1}$ body weight (mifepristone). Isoxuprine hydrochloride was dissolved in water for injection at $1 \mathrm{ml} \mathrm{kg}{ }^{-1}$.

\section{Determination of uterine contractile activity}

\section{Rats injected with mifepristone}

The animals were anaesthetized with $60 \mathrm{mg}$ sodium pentobarbitone $\mathrm{kg}^{-1}$ (M\&B, Dagenham, UK) subcutaneously and uterine contractions were recorded at $2,4,8,12,24,36$ or $48 \mathrm{~h}$ after mifepristone injection, using the microballoon technique as described previously (Arkaravichien \& Kendle, 1992). The rats were left to stabilize for $1 \mathrm{~h}$ and then the contractile activity was recorded on a Washington oscillograph for $2 \mathrm{~h}$.

Control rats were injected with $1 \mathrm{mg}$ sesame oil in mifepristone vehicle $\mathrm{kg}^{-1}$ and uterine contractions were recorded at 12,24 or $48 \mathrm{~h}$ after injection.

\section{Ovariectomized rats}

Rats were ovariectomized on day 15 of pregnancy and injected with $200 \mathrm{ng}$ oestradiol benzoate day ${ }^{-1}$. They were anaesthetized and uterine contractions were recorded at $8,12,24,36$ or $48 \mathrm{~h}$ after ovariectomy. Control rats were ovariectomized on day 15 and injected with $4 \mathrm{mg}$ progesterone plus $200 \mathrm{ng}$ oestradiol benzoate daily. Their uterine contractility was recorded at $12,24,36$ or $48 \mathrm{~h}$ after operation.

Other groups of rats were ovariectomized and treated with oestradiol benzoate then left for $24 \mathrm{~h}$ for the development of uterine contractions, before $4 \mathrm{mg}$ progesterone plus $200 \mathrm{ng}$ oestradiol benzoate was injected. Their uterine contractions were recorded during $2-6,6-10$ or $18-24 \mathrm{~h}$ after progesterone injection to see whether progesterone suppressed the well-developed uterine contractions.

\section{Determination of fetal viability and fetal growth}

\section{Rats injected with mifepristone}

Rats injected with mifepristone on day 15 of pregnancy were killed at 36,42 or $48 \mathrm{~h}$ after injection for the determination of fetal viability. Fetuses were quickly removed from the uteri and examined for survival as indicated by the presence of a heart beat. The number of surviving fetuses and the number of implantation sites were counted and the proportion of viable fetuses was calculated. A further group of rats, injected with $1 \mathrm{ml}$ vehicle $\mathrm{kg}^{-1}$ on day 15 as a control, was killed at $48 \mathrm{~h}$ after injection for determination of fetal viability.

\section{Ovariectomized rats}

Ovariectomized rats injected with oestradiol were killed at 42 or $48 \mathrm{~h}$ after ovariectomy, and fetal viability was determined. Control rats were ovariectomized and injected with $4 \mathrm{mg}$ progesterone plus $200 \mathrm{ng}$ oestradiol benzoate daily and killed $48 \mathrm{~h}$ after ovariectomy.

Fetal viability and fetal growth, after inducing a period of prolonged uterine contractions before progesterone was given, were studied by delaying progesterone replacement to ovariectomized rats for 24 or $36 \mathrm{~h}$. The animals were 
killed on day 18 or 21 , when fetal viability was calculated and numbers of misformed fetuses and apparently normal fetuses were counted. The apparently normal fetuses were weighed and their lengths were measured; these values were compared with those from ovariectomized rats with immediate progesterone replacement.

\section{Effects of isoxuprine on uterine contractility, fetal viability and fetal growth}

A $\beta$-adrenoceptor agonist, isoxuprine, was tested for suppressive effect on uterine contractility and for the

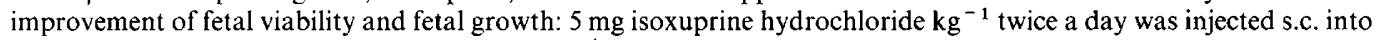
rats that were treated with $2 \mathrm{mg}$ mifepristone $\mathrm{kg}^{-1}$ on day 15 . The uterine contractions were recorded and compared with those in rats treated with mifepristone alone. Fetal viability at $42 \mathrm{~h}$ after mifepristone injection was compared in rats receiving and not receiving isoxuprine.

Similarly, $5 \mathrm{mg}$ isoxuprine hydrochloride $\mathrm{kg}^{-1}$ was injected s.c. twice a day into rats ovariectomized on day 15 of pregnancy and uterine contractility was recorded $24 \mathrm{~h}$ after ovariectomy. Fetal viability was compared in ovariectomized rats with and without isoxuprine injection. Isoxuprine was also tested to see whether it increased fetal viability and growth in rats that had been allowed to develop prolonged uterine contractions for a period before progesterone was replaced: $5 \mathrm{mg}$ isoxuprine hydrochloride $\mathrm{kg}^{-1}$ was injected twice a day on days 15 and 16 and once on the morning of day 17 into ovariectomized rats in which progesterone was delayed for $36 \mathrm{~h}$. They were killed on day 21 and fetal viability and growth were determined.

\section{Statistical analysis}

The amplitude and force of uterine contractions were determined and calculated as Montevideo units, i.e. the product of the average number of contractions in $10 \mathrm{~min}$ and their mean amplitude (Alvarez \& Caldeyro-Barcia, 1950). The contractile activity was presented as means \pm SD and significance of difference between two treatment groups was tested by Student's $t$ test.

Significance of difference in fetal viability between each treatment group was determined by the $\chi^{2}$ test. Fetal length and weight were expressed as means \pm SD and significance of difference between two treatment groups was by Student's $t$ test and between more than two treatment groups by analysis of variance followed by the Kramer modification of Duncan's multiple-range test, where appropriate (Milton \& Tsokos, 1983).

\section{Results}

\section{Rats injected with mifepristone}

At $2 \mathrm{~h}$ after injection with mifepristone, the contractile pattern and activity (in Montevideo units) were not significantly different from that in control rats (Fig. 1a). From $4 \mathrm{~h}$ after injecting with mifepristone, uterine contractions were significantly stronger than at $2 \mathrm{~h}$. Uterine contractions after injecting with mifepristone, at 12,24 or $48 \mathrm{~h}$, were significantly stronger than in rats injected with vehicle at the same times (Fig. 2).

Fetal viability at $36 \mathrm{~h}$ after mifepristone injection, when contractions had lasted for $32 \mathrm{~h}$ (from 4 to $36 \mathrm{~h}$ ), was not significantly different from that in rats injected with vehicle $48 \mathrm{~h}$ previously. At 42 and $48 \mathrm{~h}$ after mifepristone injection, fetal viability was significantly reduced (Table 1 ).

Isoxuprine significantly reduced uterine contractile activity in rats injected with mifepristone from 104 Montevideo units, (SD 24, $n=10$ ) in controls to 36, (SD 13, $n=6$ ) in the treated group, but it did not improve fetal viability determined $42 \mathrm{~h}$ after mifepristone injection (Table 1 ).

\section{Ovariectomized rats}

At $8 \mathrm{~h}$ after ovariectomy, the uterine contractile pattern was similar to that in ovariectomized rats treated with progesterone plus oestradiol and similar to that in intact rats injected with vehicle. Contractile activity (in Montevideo units) $8 \mathrm{~h}$ after ovariectomy was not significantly different from that at 12 or $24 \mathrm{~h}$ in ovariectomized rats with progesterone replacement. Contractility at 12 and $24 \mathrm{~h}$ after progesterone withdrawal was significantly higher than in ovariectomized rats with progesterone supplement. Values for uterine contractions in animals in which progesterone had been withdrawn were still high at 36 and $46 \mathrm{~h}$ (Fig. 3). 
(a)

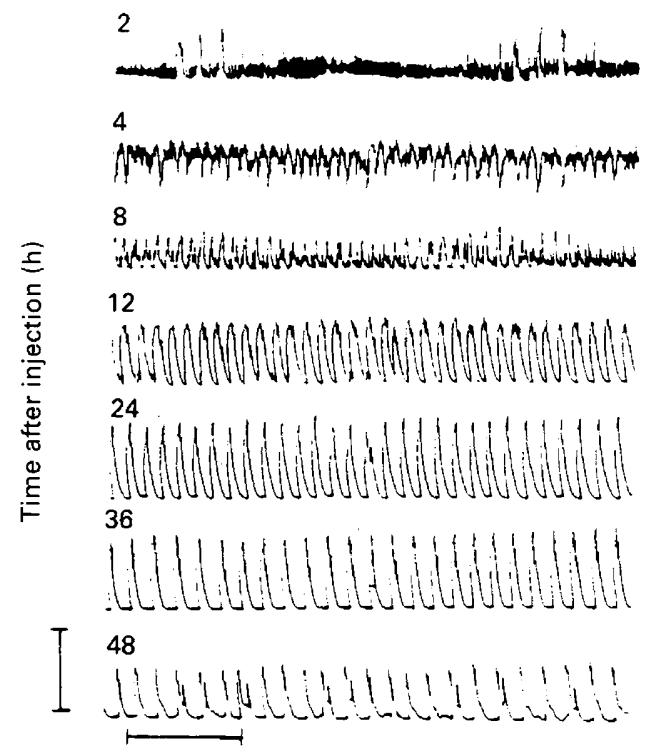

(b)

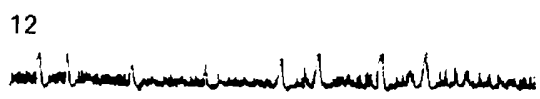

24

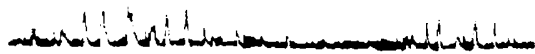

(c)

8
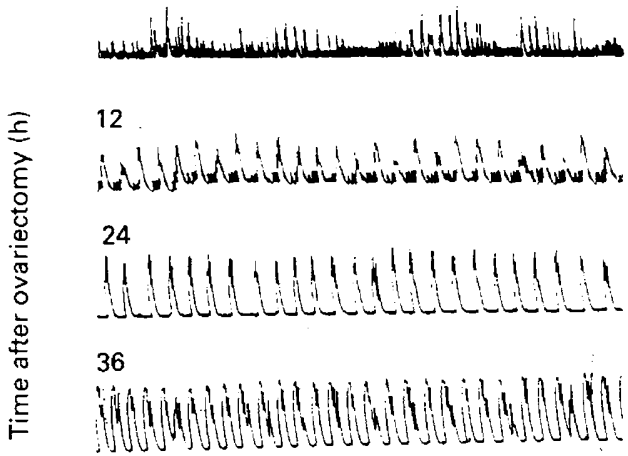

(d)

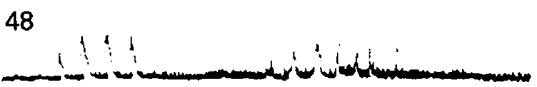

48

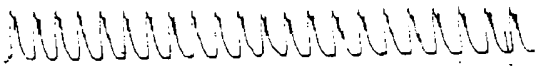

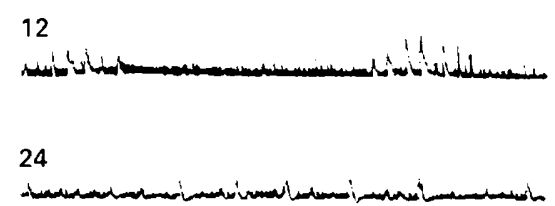

36

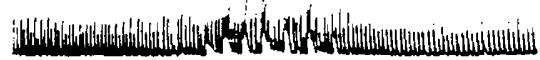

48

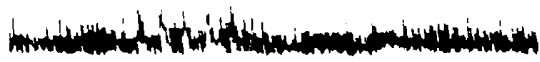

Fig. 1. Uterine contractile patterns in rats at different times after (a) injecting with $2 \mathrm{mg}$ mifepristone $\mathrm{kg}^{-1}$, (b) injecting with $1 \mathrm{ml}$ sesame oil kg-1, (c) ovariectomy on day 15 of pregnancy and treatment with $200 \mathrm{ng}$ oestradiol benzoate day ${ }^{-1}$, and (d) ovariectomy on day 15 of pregnancy and treatment with $4 \mathrm{mg}$ progesterone plus $200 \mathrm{ng}$ oestradiol benzoate day ${ }^{-1}$. Horizontal bar: $10 \mathrm{~min}$; vertical bar: $20 \mathrm{~mm} \mathrm{Hg}$.

Although the uterine contractile pattern at 12 and $24 \mathrm{~h}$ after ovariectomy with progesterone replacement was similar to that in intact animals, the contractile pattern at 36 and $48 \mathrm{~h}$ after operation with progesterone replacement was different from that in intact animals (Fig. 1d).

Fetal viability $42 \mathrm{~h}$ after ovariectomy, when uterine contractions had lasted for $30 \mathrm{~h}$ (from 12 to $42 \mathrm{~h}$ ), was not significantly different from that in ovariectomized rats with progesterone replacement. At $48 \mathrm{~h}$ after ovariectomy, fetal viability was significantly reduced (Table 2 ). 


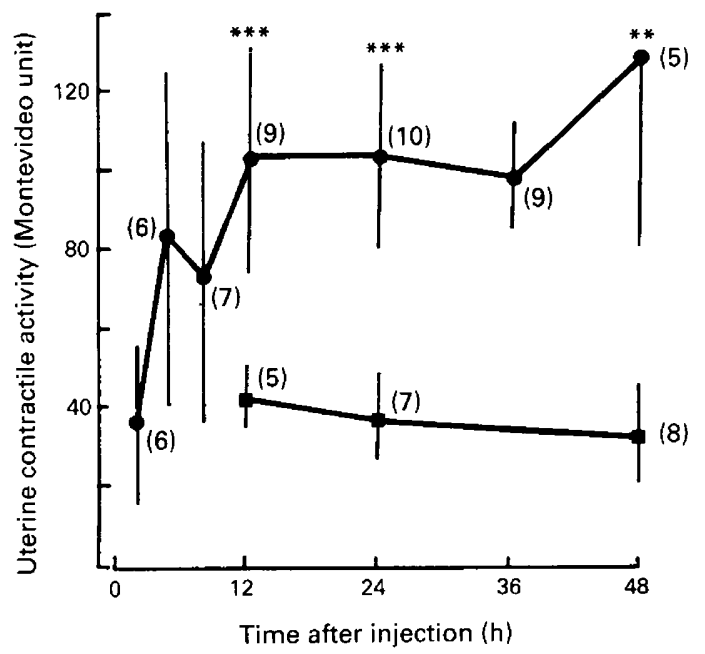

Fig. 2. Uterine contractile activity in rats injected with $2 \mathrm{mg}$ mifepristone $\mathrm{kg}^{-1}(\bullet)$ or $1 \mathrm{ml}$ sesame oil $\mathrm{kg}^{-1}(\boldsymbol{\square})$ on day 15 of pregnancy. Numbers in parentheses are the numbers of rats used; ${ }^{* *}$ significantly different from rats injected with vehicle at the same time $(P<0.01)$; *** significantly different from rats injected with vehicle at the same time $(P<0 \cdot 001)$.

Table 1. Fetal viability at different times after injecting rats with $2 \mathrm{mg}$ mifepristone $\mathrm{kg}^{-1}$ or $1 \mathrm{ml}$ vehicle $\mathrm{kg}^{-1}$ on day 15 of pregnancy and the effect of injecting $5 \mathrm{mg}$ isoxuprine hydrochloride $\mathrm{kg}^{-1}$ twice a day on the improvement of fetal viability in rats receiving mifepristone

\begin{tabular}{lccc}
\hline Treatment & $n$ & $\begin{array}{c}\text { Time since } \\
\text { injection } \\
\text { (h) }\end{array}$ & $\begin{array}{c}\text { Fetal viability } \\
(\%)\end{array}$ \\
\hline Vehicle & 7 & 48 & $102 / 109(93 \cdot 6)$ \\
Mifepristone & 11 & 36 & $144 / 167(86 \cdot 2)$ \\
Mifepristone & 17 & 42 & $150 / 239(62 \cdot 8)^{* * *}$ \\
Mifepristone & 12 & 48 & $93 / 177(52 \cdot 5)^{* * *}$ \\
Mifepristone + isoxuprine & 9 & 42 & $55 / 123(44 \cdot 7)^{* * *}$ \\
\hline
\end{tabular}

*** Significantly different from each of the first two groups, which are not significantly different from each other, $\left(P<0.001, \chi^{2}\right)$.

When $4 \mathrm{mg}$ progesterone plus $200 \mathrm{ng}$ oestradiol benzoate was injected into ovariectomized rats that had been left to develop uterine contractions for a day, progesterone significantly suppressed uterine contractions within $6 \mathrm{~h}$ and the contractile activity $24 \mathrm{~h}$ after progesterone injection was not significantly different from that in intact animals (Fig. 4). Fetal viability and growth in rats with progesterone replacement delayed for $24 \mathrm{~h}$ were not significantly different from that in ovariectomized rats receiving progesterone replacement immediately (Table 3 ). When progesterone replacement was delayed to $36 \mathrm{~h}$ after ovariectomy, fetal viability and growth determined on day 21 were significantly reduced, even though no significant differences were evident in fetal viability or growth between ovariectomized rats with delayed or immediate progesterone treatment when the rats were killed on day 18 .

In ovariectomized rats, isoxuprine also significantly reduced uterine contractile activity at $24 \mathrm{~h}$ after ovariectomy, from 118 Montevideo units (SD 20,n=11) in the control to 82 (SD 23, $n=9$ ) in the treated group. Fetal viability $48 \mathrm{~h}$ after ovariectomy in rats receiving isoxuprine was 


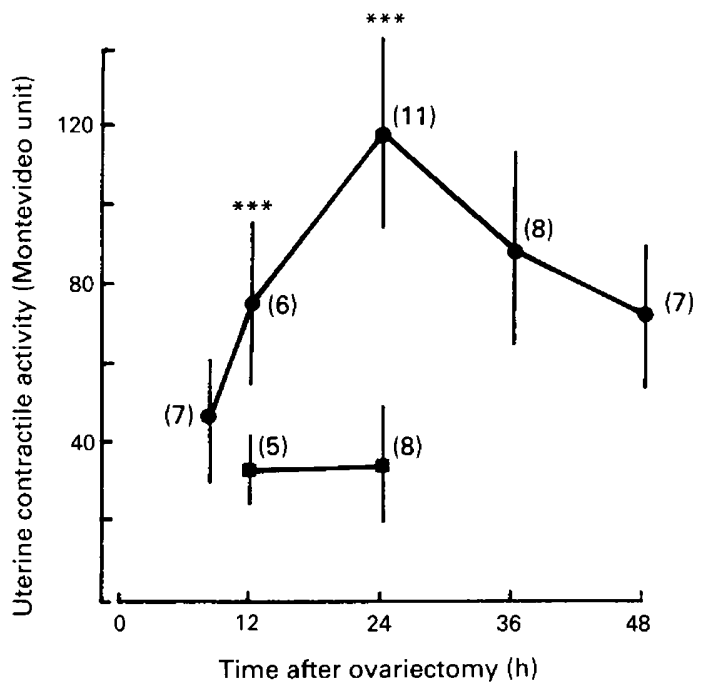

Fig. 3. Uterine contractile activity in rats ovariectomized on day 15 of pregnancy and injected with $200 \mathrm{ng}$ oestradiol benzoate day ${ }^{-1}(\bullet)$ or $4 \mathrm{mg}$ progesterone plus $200 \mathrm{ng}$ oestradiol benzoate day $^{-1}(\boldsymbol{\square})$. Numbers in parentheses are the numbers of rats used; ${ }^{* * *}$ significantly different from ovariectomized rats with progesterone replacement at the same time $(P<0.001)$.

Table 2. Fetal viability at different times after ovariectomy in rats treated with $200 \mathrm{ng}$ oestradiol benzoate day ${ }^{-1}$ or $4 \mathrm{mg}$ progesterone plus $200 \mathrm{ng}$ oestradiol $\mathrm{day}^{-1}$ and the effect of injecting $5 \mathrm{mg}$ isoxuprine hydrochloride $\mathrm{kg}^{-1}$ twice a day on fetal viability in rats in which progesterone withdrawal had been induced by ovariectomy

\begin{tabular}{|c|c|c|c|}
\hline Treatment & $n$ & $\begin{array}{c}\text { Time since } \\
\text { ovariectomy } \\
\text { (h) }\end{array}$ & $\begin{array}{l}\text { Fetal viability } \\
\qquad(\%)\end{array}$ \\
\hline Oestradiol + progesterone & 8 & 48 & $99 / 110(90 \cdot 0)$ \\
\hline Oestradiol & 10 & 42 & $125 / 139(89.9)$ \\
\hline Oestradiol & 9 & 48 & $95 / 137(69 \cdot 3)^{* * *}$ \\
\hline Oestradiol + isoxuprine & 11 & 48 & $125 / 150(83 \cdot 3)$ \\
\hline
\end{tabular}

*** Significantly different from the other three groups, which are not significantly different from one another, $\left(P<0.001, \chi^{2}\right)$.

significantly improved from $69 \cdot 3$ to $83 \cdot 3 \%$ (Table 2), but isoxuprine did not improve fetal viability, determined on day 21 , in ovariectomized rats in which progesterone replacement had been delayed for $36 \mathrm{~h}$. Nevertheless, fetal length and weight in rats receiving isoxuprine were greater than in controls (Table 3 ).

\section{Discussion}

This study demonstrated that uterine contractility in midpregnancy in rats was increased significantly by progesterone withdrawal either by using the antiprogestational steroid mifepristone or by ovariectomy. As the microballoon technique of intrauterine pressure recording was used, there is always a danger that the observed results are an artefact due to the insertion or presence of the 


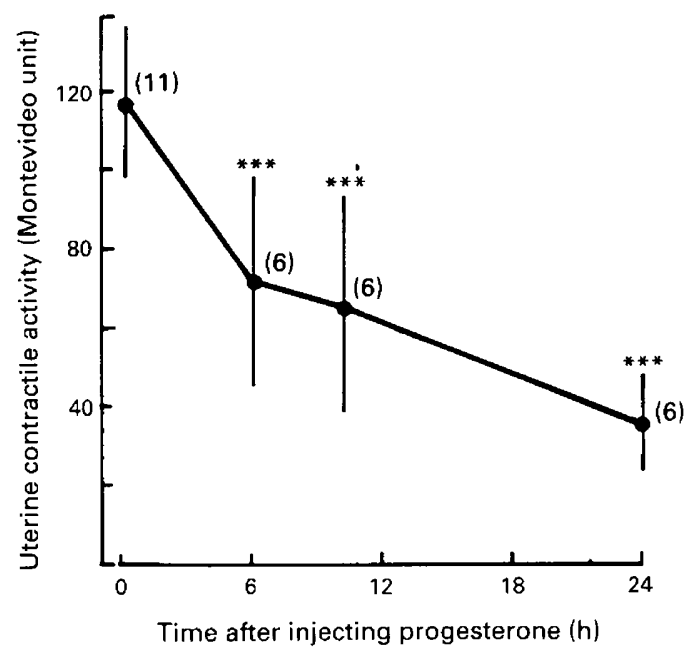

Fig. 4. Uterine contractile activity after injecting $4 \mathrm{mg}$ progesterone plus $200 \mathrm{ng}$ oestradiol benzoate into ovariectomized rats that had been treated with $200 \mathrm{ng}$ oestradiol benzoate and left to develop full uterine contractions for $24 \mathrm{~h}$. Numbers in parentheses are the numbers of rats used; $* * *$ significantly different from the contractile activity before progesterone injection $(P<0.001)$.

balloon. The results showed, however, that progesterone withdrawal leads to an increase in uterine contractile activity which was not observed in intact control animals with implanted balloons. Recordings were taken $1 \mathrm{~h}$ after insertion of the microballoon to allow time for prostaglandin production to return to normal before recording commenced. These factors have been discussed in greater detail (Arkaravichien \& Kendle, 1992).

Replacing progesterone in the ovariectomized rats prevented the increase in uterine contractions, recorded at 12 and $24 \mathrm{~h}$. A dose of $4 \mathrm{mg} \mathrm{day}^{-1}$ was chosen for replacement as previous studies in this colony of rats showed that $3 \mathrm{mg}^{\mathrm{day}}{ }^{-1}$ gave serum progesterone concentrations lower than those in normal pregnant rats (Arkaravichien \& Kendle, 1990). However, uterine contractions recorded at 36 and $48 \mathrm{~h}$ after ovariectomy in rats treated with progesterone plus oestradiol were different from those in intact animals injected with vehicle, possibly because the ovariectomized rats lacked some other myometrial inhibitory hormones produced by the ovary, such as relaxin. There is evidence that relaxin, which increases during pregnancy, inhibits myometrial activity in rats in vitro (Sanborn et al., 1980; Sarosi et al., 1983) and in vivo (Bradshaw et al., 1981; Downing \& Sherwood, 1985).

When uterine contractions had been left to develop fully and progesterone was injected $24 \mathrm{~h}$ later, progesterone suppressed the well-developed uterine contractions; i.e. progesterone had preventive and suppressive actions on uterine contractility in midpregnancy in rats, but failed to inhibit myometrial contractions induced by ovariectomy post partum (Porter \& Challis, 1974). The reason for these contrasting findings is possibly because of the difference in progesteronebinding affinity between the midpregnancy and post partum stages. Downing et al. (1978) have demonstrated that the apparent equilibrium constant of progesterone binding in pregnant rats on day 18 is higher than in post partum rats. Alternatively, the ratio of progesterone:oestrogen, rather than the concentration of progesterone itself, may explain these different results.

This study demonstrated that prolonged uterine contractions up to a certain time, $32 \mathrm{~h}$ in the case of mifepristone and $30 \mathrm{~h}$ in the case of ovariectomy, did not significantly reduce fetal viability. However, if the pregnant rats were left to a condition of progesterone withdrawal for a longer period, it resulted in significantly lower fetal viability. Isoxuprine was administered to determine whether fetal viability improved when uterine contractions were reduced. Isoxuprine suppressed 


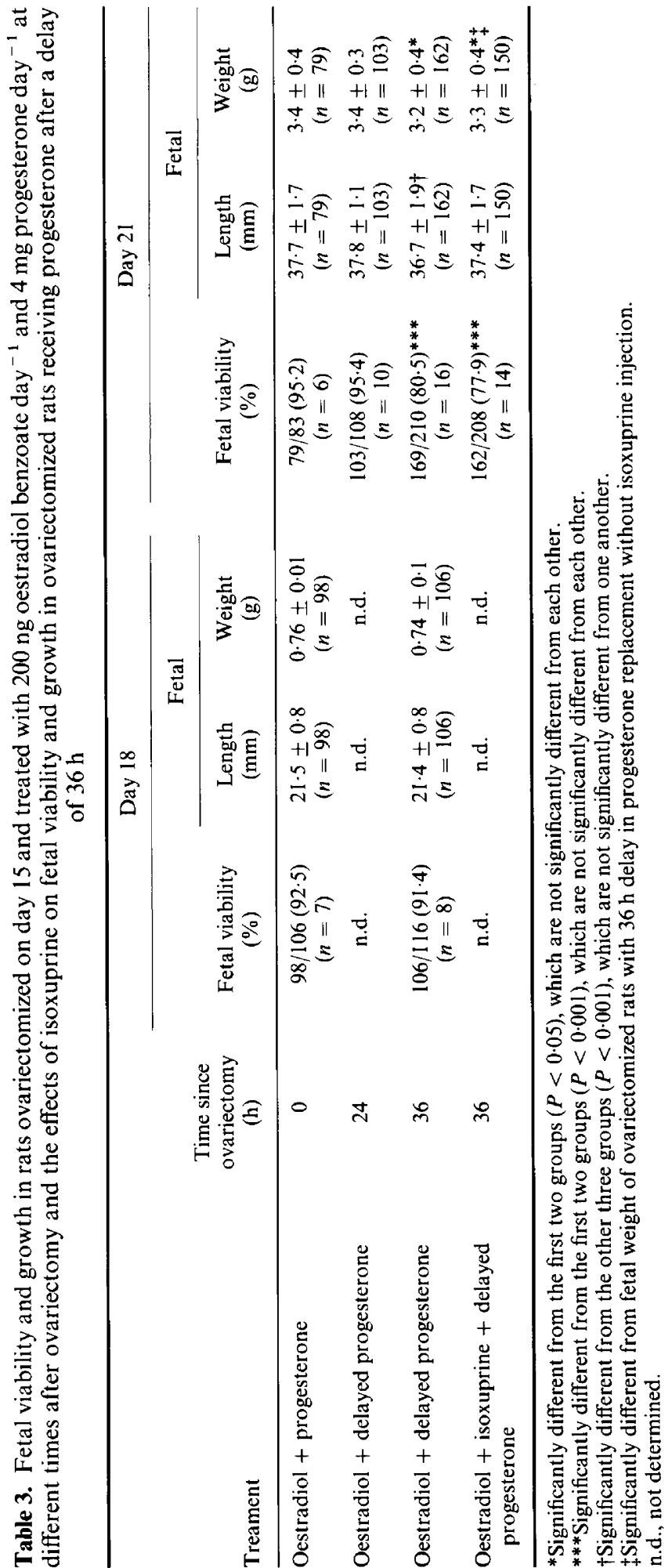


uterine contractions in mifepristone-treated and ovariectomized rats, but improved fetal viability only in ovariectomized rats. This was not surprising because mifepristone has been shown to have a luteolytic effect apart from the effect on the myometrium, in culture of ovarian cells from pregnant rats (Arakawa et al., 1990) and in intact pregnant rats (Kawano et al., 1988; Singh et al., 1988). The decrease in luteal steroid hormones, especially oestrogens, may be an additional cause of fetal death that is not counteracted by isoxuprine.

Delaying progesterone replacement for $36 \mathrm{~h}$, during which uterine contractions had lasted for about $30 \mathrm{~h}$ (from 12 to $36 \mathrm{~h}$ after ovariectomy plus $6 \mathrm{~h}$ of the onset of progesterone suppressive action), did not significantly reduce fetal viability or growth determined on day 18 , but, 3 days later on day 21 , fetal viability and fetal growth were significantly reduced, whereas delaying progesterone for $24 \mathrm{~h}$ did not significantly affect fetal survival or growth. In addition, seven out of 169 fetuses in ovariectomized rats with a progesterone delay of $36 \mathrm{~h}$ showed some malformation, e.g. haematomata or fetal elongation, whereas fetuses from ovariectomized rats with a progesterone delay of $24 \mathrm{~h}$ were all apparently normal. This indicates that the deprivation of progesterone and the prolongation of uterine contractions had effects on fetal survival and fetal growth which were not seen when rats were killed earlier. Although prolonged uterine contractions for about $30-32 \mathrm{~h}$ did not cause immediate death, they did reduce fetal survival and fetal growth at a later stage.

When isoxuprine, which had been shown to suppress uterine contractions and improve fetal viability at an earlier stage, was injected into ovariectomized rats with delayed progesterone replacement, isoxuprine failed to improve fetal viability at the later stage of pregnancy. Nevertheless, in ovariectomized rats fetal growth was significantly higher in those treated with isoxuprine than in those without isoxuprine treatment, although fetal weight was still significantly lower than in ovariectomized rats injected with progesterone immediately. This could imply that isoxuprine, as a $\beta$-adrenoceptor agonist, may act on the vascular receptors resulting in an increase in blood flow to uteri and to the feto-placental unit, thus enhancing fetal growth.

The mechanism by which progesterone withdrawal causes termination of pregnancy is not fully understood. Prolonged uterine contraction, as shown in this study, could be the cause of fetal death. Selye et al. (1935) found that fetuses developed normally when they were relieved from the abnormally high intra-uterine pressure after ovariectomy by extrusion into the abdominal cavity. Similarly, Frazer (1955) demonstrated that liberation of fetuses of the ovariectomized rats from the uteri into the peritoneal cavity significantly reduced the incidence of fetal death. Alternatively, progesterone withdrawal may cause the reduction in fetal viability by reducing the blood flow to the uterus and to the feto placental unit; Ford et al. (1979) have shown that uterine blood flow in cows is positively correlated with the oestradiol:progesterone ratio. Other possible mechanisms, such as the abolition of the suppressive immunological effect of progesterone, as proposed by Siiteri et al. (1977), or the changes of histopathology of the contacting site between uterine wall and placenta after progesterone withdrawal, may be the cause of fetal death.

It may be concluded from the present study that there is a strong association between progesterone withdrawal, sustained uterine contractile activity and loss of fetal viability. Reduction of contractile activity, by progesterone replacement or by pharmacological inhibition, can increase fetal survival, but further work is required to establish whether uterine contractions are a direct or an indirect cause of fetal death.

\section{References}

Alvarez, H. \& Caldeyro-Barcia, R. (1950) Contractility of the uterus recorded by new methods. Surgery Gynecology and Obstetrics 91, 1-13.

Arakawa, S., Kambegawa, A., Okimaga, S. \& Arai, K. (1990) Luteolytic effect of the antiprogestin and antiglucocorticoid agent RU 486 in rats. Journal of Steroid Biochemistry 36, 479-483.
Arkaravichien, W. \& Kendle, K.E. (1990) Critical progesterone requirement for maintenance of pregnancy in ovariectomized rats. Journal of Reproduction and Fertility 90, 63-70.

Arkaravichien, W. \& Kendle, K.E. (1992) Rat uterine contractile activity induced by mifepristone (RU $486)$ is independent of uterine prostaglandin $E_{2}$ 
and prostaglandin $F_{2 a}$ concentrations. Journal of Reproduction and Fertility 94, 177-188.

Bradshaw, J.M.C., Downing, S.J., Moffatt, A., Hinton, J.C. \& Porter, D.G. (1981) Demonstration of some of the physiological properties of rat relaxin. Journal of Reproduction and Fertility 63, 145-153.

Clabault, M., Duclos, R. \& Acritopoulou-Fourcroy, S. (1988) Increase of uterine motility and simultaneous decrease of progesterone concentrations in the rat after bilateral ovariectomy at mid-pregnancy. Journal of Reproduction and Fertility 82, 545-551.

Downing, S.J. \& Sherwood, O.D. (1985) The physiological role of relaxin in the pregnant rat. II. The influence of relaxin on uterine contractile activity. Endocrinology 116, 1206-1214.

Downing, S.J., Lye, S.J., Bradshaw, J.M.C. \& Porter, D.G. (1978) Rat myometrial activity in vivo: effects of oestradiol-17 $\beta$ and progesterone in relation to the concentrations of cytoplasmic progesterone receptors. Journal of Endocrinology 78, 103-117.

Ford, S.P., Chenault, J.R. \& Echternkamp, S.E. (1979) Uterine blood flow of cows during the oestrous cycle and early pregnancy: effect of the conceptus on the uterine blood supply. Journal of Reproduction and Fertility 56, 53-62.

Frazer, J.F.D. (1955) The mechanism of fetal loss after pregnant rats are spayed. Journal of Physiology 130, 253-256.

Fuchs, A.R. (1973) Parturition in rabbits and rats. In Endocrine Factors in Labour, pp. 163-185. Eds A. Klopper \& J. Gardner. Cambridge University Press, Cambridge.

Inoue, S. (1981) Experimental simulation of neuroendocrine dynamics at parturition periods: a synthetic approach to pregnancy maintenance, parturition and lactation by programmed infusion of sex steroids in ovariectomized rats. Endocrinologica Japonica 28, 747-755.
Kawano, T., Okamura, H., Tajima, C., Fukuma, K. \& Katabuchi, H. (1988) Effect of RU 486 on luteal function in the early pregnant rat. Journal of Reproduction and Fertility 83, 279-285.

Milton, J.S. \& Tsokos, J.O. (1983) Statistical Methods in The Biological and Health Sciences. McGraw-Hill, Inc., New York.

Porter, D.G. \& Challis, J.R.G. (1974) Failure of high uterine concentrations of progesterone to inhibit myometrial activity in vivo in the post-partum rat. Journal of Reproduction and Fertility 39, 157-162.

Sanborn, B.M., Kuo, H.S., Weisbrodt, N.W. \& Sherwood, O.D. (1980) The interaction of relaxin with the rat uterus. I. Effects on cyclic nucleotide levels and spontaneous contractile activity. Endocrinology 106, 1210-1215.

Sarosi, P., Schmidt, C.L., Essig, M., Steinetz, B.G. \& Weiss, G. (1983) The effect of relaxin and progesterone on rat uterine contractions. American Journal of Obstetrics and Gynecology 145, 402-405.

Selye, H., Collip, J.B. \& Thomson, D.L. (1935) Endocrine interactions during pregnancy. Endocrinology 19, 151-159.

Siiteri, P.K., Febres, F., Clemens, L.E., Chang, R.J., Gondos, B. \& Stites, D. (1977) Progesterone and maintenance of pregnancy: is progesterone nature's immunosuppressant? In Biochemical Actions of Progesterone and Progestins, pp. 384-397. Ed. E. Gurpide. Annals of the New York Academy of Sciences, vol. 286, New York.

Singh, G., Singh, M.M., Maitra, S.C., Elger, W., Kalra, V., Upadhyay, S.N., Chowdhury, S.R. \& Kamboj, V.P. (1988) Luteolytic action of two antiprogestational agents (RU 38486 and ZK 98734) in the rat. Journal of Reproduction and Fertility 83, 73-83.

Received 21 August 1991 